\title{
The Effectiveness of Accounting Information Systems in Reducing the Risks of Electronic Auditing: Applied Study on Irbid's Electricity Company of Jordan
}

\author{
Thaker Abdulah Sayed ${ }^{1}$ \\ ${ }^{1}$ Irbid National University, Jordan \\ Correspondence: Thaker Abdulah Sayed, Irbid National University, Jordan. E-mail: thakrmassarwa@gmail.com
}

Received: January 15, 2019

Accepted: February 21, 2019 Online Published: March 18, 2019

doi:10.5539/ijbm.v14n4p205

URL: https://doi.org/10.5539/ijbm.v14n4p205

\begin{abstract}
Accounting information systems and their outputs are efficient management tools that are based on information in decision making. The external auditor is keen to ensure that the company has sophisticated and modern accounting information systems capable of meeting its auditing needs. This study aimed at identifying the effectiveness of accounting information systems (Relevance, Reliability and Information security) to reduce the risk of electronic auditing (inherent, control, detection) in Irbid Electricity Company. In order to achieve the objectives of the study, a questionnaire was designed and distributed to the sample of the study which consisted of (152) employees who were financial managers, account managers, internal auditors and employees working in the company's information technology departments. The number of questionnaires retrieved and statistical analysis was (136). To analyze data and test hypotheses, the statistical program (SPSS) was used. The study found that there is a significant effect on the effectiveness of accounting information systems on the risks of electronic auditing in Irbid Electricity Company. The study recommended that more researches should be accomplished on achieving efficiency, efficiency in the procedures of accounting control, and asset protection programs to reduce the risk of control.
\end{abstract}

Keywords: effectiveness of accounting information systems, risk of electronic auditing, Irbid Electricity Company

\section{Introduction}

In the last few years, a quick technological development of information has been witnessed, a matter which led companies to develop their systems to cope up with the huge development of systems in the field of information technology and communication. This has intensified the competition among the companies, and led the companies to encounter great challenges; therefore, it has become necessary to respond to these changes with a clear vision that enables them to diagnose and manage risks, and also to manage the size of opportunities. So, all the previous challenges and changes necessarily require the companies to develop the methods to manage and enhance their ability to get benefit from those opportunities.

In order to respond to changes in the development of information technology and reduce electronic risks as a unit to access the largest exploitation of opportunities and use the information, as a suitable source of appropriate economic decisions, mutual trust between the auditor and relevant parties of providers and users of financial information should be established, especially in the mean time, as the risks of electronic auditing are threatening the auditor's work, we need to identify the risks of auditing and the extent of the risk.

\subsection{Problem of the Study}

Accounting information systems and their outputs are efficient management tools that are based on information in decision making. The use of high-efficiency accounting systems that are appropriate, consistent and secure to provide management information and users with accounting information is one of the most important requirements for improving financial performance.

The external auditor is keen to ensure that the company has sophisticated and modern accounting information systems capable of meeting its auditing needs, a matter which makes traditional accounting information systems unable to assist in auditing. Therefore, the company must strive to develop accounting information systems along 
with the tremendous developments in the surrounding environment.

\subsection{Significance of the Study}

The importance of this study stems from the risks of electronic auditing which is one of the strategic objectives that the company seeks to achieve, especially in an environment that prevails a tremendous development in information systems, both locally and abroad, by focusing on its dimensions.

\subsection{Study Objectives}

This study is designed to achieve the following aims:

1. Identify the effectiveness of accounting information systems to reduce the risk of electronic auditing;

2. Identify the effectiveness of accounting information systems to reduce the risk of discovery;

3. Identify the effectiveness of accounting information systems to reduce the inherent risks;

4. Identify the effectiveness of accounting information systems to reduce the risk of censorship.

\subsection{Study Hypotheses}

The hypotheses of the study were based on the previous studies that dealt with the risks of electronic auditing (Abu Alim, 2016). The current study is based on the studies that examined the effectiveness of accounting information systems, especially the study (Akor, 2014). The questions raised by the study and the aims seek to achieve the following hypotheses:

HO: There is no statistically significant impact of the effectiveness of accounting information systems (relevance, reliability, information security) on the risks of electronic auditing (discovery, control, inherent) on Irbid's electricity company.

HO1: There is no statistically significant effect of the effectiveness of accounting information systems (relevance, reliability, information security) on the risk of discovery on Irbid's electricity company.

HO2: There is no statistically significant effect of the effectiveness of accounting information systems (relevance, reliability, information security) on the risk of control over Irbid's electricity company.

HO3: There is no statistically significant effect of the effectiveness of accounting information systems (relevance, reliability, information security) on the risks associated with Irbid's electricity company.

\subsection{The Study Model}

Independent variable

Dependent variable

\begin{tabular}{|c|c|}
\hline Accounting Information Systems & Electronic auditing risks \\
\hline Relevance & Risk of Discovery \\
\hline Reliability & Control Risks \\
\hline Information security & Inherent Risks \\
\hline
\end{tabular}

Figure 1. The study model

Source: Prepared by the researcher based on the studies: (Alkour: 2014); (Abu Salem: 2016), (Kharabsha: 2018).

\section{Theoretical Framework}

The huge development in technology in the light of globalization is characterized by the age of information, as economic units of different types have a large amount of data which must have information systems with specific characteristics and standards within the controls to obtain accounting information that is appropriate and reliable (Kharabshe, 2018).

The concept of accounting information systems is defined by Kieso (2016, p. 68) as: "those systems responsible for the collection and processing of process data, and then the dissemination of financial information to the parties concerned, vary from one organization to another depending on the size of the organization and the nature of the activity and processes therein". These systems, which collect data (financial and non-financial), are processed, analyzed, and tabulated to convert accounting information to provide users with internal and external 
accounting information to assist decision makers. The researcher believes that the accounting information system is a concrete information system that "deals with the financial information related to the organization and performs all the functions of the information systems from collecting, sorting, processing, analyzing, communicating and presenting those data to those concerned within or outside the organization to make appropriate decisions" ( Romney \& Steinbart, 2016).

The accounting information systems consist of elements that contribute to the production of data in the final form. In order to achieve the goals and objectives of the accounting information systems, the organization must design systems that conform to its nature and function. It has to conduct studies of its working environment and the current accounting system, so the collected data will help it in developing the principles for updating the current system and laying the foundation for the system, and then use it in the work of the Organization (Sufian, 2012). According to (Rommeny \& Steinbart: 2016), the components of accounting information systems contain information and data infrastructure related to the company's operations and software used to process information, procedures, instructions and internal controls of procedures that protect data in the accounting information system and data storage unit which retrieves used and unused information when needed.

The management extensive reliance on accounting information systems to cover the management increasing needs of the necessary accounting information to make the appropriate decisions makes it depend on the various analytical methods necessary to analyze these data and increase their efficiency, relevance, and support decision-making processes that entail the support of the accounting information system. Therefore, the management of the organization seeks to use and attract people with expertise and competence, providing accounting information systems with adequate protection, and obtaining accurate and appropriate information (Dbaghia, 2011). The followings are important characteristics of the outputs of the accounting information:

1- Reliability: Is one of the basic characteristics of accounting information and is considered as the basis for decision-making and reliance. It indicates that the information is free from errors and bias and the representation of its content is fair and honest (Keiso et al., 2016).

2- Relevance: Information that is relevant to decision-making and is influenced by user decisions and teams to help them assess all past, current and upcoming events (Jawabreh \& Alarabei, 2013).

3- Information security: It is one of the most important things in which management focuses on the control of accounting information systems, as it seeks to protect them from the illegal access of the physical and logical components in order to reduce the risks of immoral and illegal use such as theft and intentional destruction, or modifying some data (Mushtahi et al., 2011).

\subsection{The Risks of Electronic Auditing}

The increasing use of information technology in accounting and financial fields has led to increased attention to the control of electronic information systems. The risks of these systems may lead to loss of confidence in accounting information, and the emergence of fundamental errors as the risks of information systems applied in companies negatively affect the integrity and the accuracy of the information disclosed in the financial statements. This made the process of assessing the risk associated with accounting information systems very important, since the external auditor's assessment of the audit risk affects the way in which the audit functions are performed and the quality of the audit. Based on the previous argument, the electronic audit risk is a key element in the financial audits under the information technology.

Accordingly, the importance of the study stems from the importance of the risk assessment process associated with the accounting information systems. Therefore, it affects the manner in which auditing functions and the quality of performed auditing. The risk assessment of electronic auditing is an essential element of financial audits under IT.

Risk is a term used to the extent of uncertainties about the processes and results that affect the company's ability to achieve its objectives (Nazmi \& Al-Mubaideen, 2015). The International Federation of Accountants (IFAC), 2010 , says that the risks that lead to an opinion by the auditor are inappropriate; so finance is remarkably wrong.

The audit risk is potential for errors in the financial information even after an audit that results from an unqualified audit result of the materially misstated financial information that led to the auditor being unable to reach these audits during the auditor's auditing (Shohnih, 2015).

\subsection{The elements of the Risk of Electronic Auditing Are the Followings:}

1. Control risks: False material data are entered into the control environment and into financial information, i.e., the company has weak internal controls exposed to audit risk (Husseini, 2009). 
2. Disclosure risk: The risk that auditors will not be able to detect material misstatement of the financial statements (Luo: 2011).

3. Consequential risks: The probability that an account or a class of transactions may contain material errors without taking account of internal accounting controls (Demartini \& Trucco, 2016).

\section{Related Literatures}

The researcher noted, through his knowledge of the research and studies that dealt with the research topics, that the scarcity of studies - according to the researcher - dealt with the relationship between the accounting information systems and the risks of electronic auditing, a matter which makes the topic of the research, according to the researcher's expectations, a distinguished one. The following is an account of the previous studies that dealt with the subject of the research:

\subsection{Previous Studies Related to the Study Variable}

The study of Barzan ( 2015) examined the role of electronic auditing in raising the efficiency of auditing. The study said that electronic auditing works to separate the work of audit, the work of the audit committees, and the enhancement of all the material and administrative requirements for electronic auditing facilitate the audit process. The study found that there are major processes in auditing electronic information systems and also showed that electronic auditing is not considered a repetitive process compared to traditional auditing in the context of increasing and evolving electronic systems. The study of Shaat (2013) examined e-commerce and its impact on the auditor's work. The study concluded that e-commerce has an important role in the audit work and affects it. Jubour (2015) accomplished a study on the effective use of electronic auditing in improving the internal control system, including the effect of increasing the efficiency and effectiveness of auditing, and the assessment of risks in periods of time to address errors before they occur. Abu Zer (2016) addressed the dependence on the outputs of accounting information systems in the decision-making process, including the attributes of importance and based on them. Aziz (2014), in a study on the important role provided by electronic auditing, including the benefit to the auditor to accomplish its task, addressed the adoption of information technology tools and modern systems in the completion of the functions of the auditor and stay away from traditional auditing as much as possible. The Gonzalez study (2018) identified electronic auditing as compared to traditional auditing, which led to difficulties in accessing fraud or hacking or manipulation because it takes random samples, but electronic auditing works continuously to mediate electronic systems and prepares clear reports on how to audit real time transactions or almost real time. According to Kharabsheh (2018), accounting information systems are reliable and help to make decisions and suitability in the preparation of financial reports, and address their development and benefit their users in making the appropriate decision. Al-Akoor (2014) said that the effectiveness of accounting information systems increases their ability to respond to changes in the external environment to contribute to decision-making. The information provided by accounting information systems can be analyzed in evaluating financial performance.

\section{Research Methodology}

\subsection{Population and Sample of the Study}

The population of the study consisted of all employees of Irbid Electricity Company in the departments of financial, accounting, auditing and information technology who were (250) employees.Sample unit comprised of financial managers, account managers, internal auditors and employees working in IT departments. The study relied on Sekaran statistical tables to determine the acceptable sample size, which was (152) employees (Sekaran \& Bougie: 2010).Questionnaires were distributed to the sample respondents, whereas the number of questionnaires retrieved and able to analyse was (136), i.e., (89.5\%) of the total distributed questionnaires.

\subsection{Instruments and Measures}

Data collection depended on the following two sources:

1- Secondary data: It included references, researches, and thesis related to the subject of the study.

2- Preliminary data: It included data collected by the questionnaire that is designed and distributed to the sample members of the study. All items of questionnaire were measured by a 5-pointLikert scale with anchors ranging from $1=$ strongly disagree to $5=$ strongly agree. Then the cells have been identified along the five Likert scale (lower and upper limits) as follows:

- Arithmetic average was considered normal (default) is the answer (3) and represents a "neutral."

- The term has been calculated according to the following equation: higher weight minus the lowest weight range $=\leftarrow(5-1=4)$ 
- The division averages for answers to five degrees represent a degree of agreement (strongly agree, agree, neutral, disagree, strongly disagree).

- The length of the cell was calculated according to the following equation: Range $\div$ number of levels $=$ length of the cell $4 \div 3=1.33$

- Added value of the length of the cell (1.33) to the beginning of the scale (the lowest value in the scale, namely, (1) to determine the upper limit for the first cell, and thus becomes the length of the cells as shown in Table 1 .

Table 1. The length of the cells five Likert scale

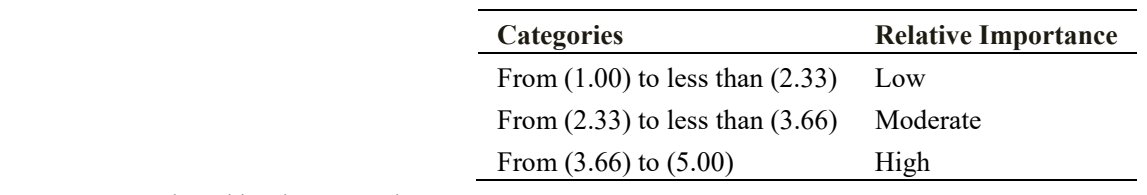

Source: Developed by the researcher.

\subsection{Statistical Tools}

The study has analyzed collected data via Statistical Package for the Social Sciences (SPSS) and to achieve the objectives of this study as follows:

- $\quad$ Frequencies and percentages: where it was used to describe the demographic data for the study sample of respondents.

- $\quad$ Arithmetic average and standard deviation: where they were used to judge the response of the study sample on the variables of the study.

- Cronbach alpha reliability coefficient and factor analysis used to verify the reliability and validity of research tool.

- $\quad$ Multiple regression method: To measure the effect of the relationship between more than one independent variable and the dependent variable.

\subsection{Reliability Test}

To test the reliability of study tool for pilot study, Cronbach's Alpha was used and the results revealed a Cronbach's alpha coefficient was $(0.943)$ for all items, and values of $(\alpha)$ range 0.702 to 0.939 , which means that the questionnaire is reliable. The values of $(\alpha)$ of the study variables of the study were as in Table 2.

Table 2. Reliability tests

\begin{tabular}{lll}
\hline No. & Dimension & Cronbach's alpha \\
\hline 1 & Relevance & 0.811 \\
2 & Reliability & 0.729 \\
3 & Information Security & 0.767 \\
$\mathbf{4}$ & Effectiveness of Accounting Information System & $\mathbf{0 . 8 9 2}$ \\
5 & Inherent Risk & 0.702 \\
6 & Control Risk & 0.818 \\
7 & Detection Risk & 0.939 \\
$\mathbf{8}$ & Electronic Audit Risk & $\mathbf{0 . 9 1 4}$ \\
$\mathbf{9}$ & All & $\mathbf{0 . 9 4 3}$ \\
\hline
\end{tabular}




\subsection{Demographic Data}

Table 3. Frequency Distribution of Demographic Data of Sample

\begin{tabular}{llll}
\hline Variable & Category & Frequency & Percentage \\
\hline \multirow{3}{*}{ Education Level } & Bachelors & 125 & 91.9 \\
& Master & 9 & 6.6 \\
& Doctoral & 2 & 1.5 \\
Scientific specialization & Accounting & 39 & 28.7 \\
& Business Administration & 30 & 22.1 \\
& Management Information Systems & 32 & 23.5 \\
Experience & accounting information systems & 35 & 25.7 \\
& Less than 5 years & 17 & 12.5 \\
Total & $\mathbf{5}$ - less than 10 years & 32 & 23.5 \\
& $\mathbf{1 0}$ - less than 15 years & 66 & 48.5 \\
& $\mathbf{1 5}$ years of more & 21 & 15.5 \\
\hline
\end{tabular}

Table 3 shows that the vast majority of the sample have a bachelor's degrees, where they reached (91.9\%). This is along with the general trend in the public and private sectors to employ a minimum bachelor's degree. It was also found that the sample members are distributed to all scientific disciplines, with an increase in specialization (accounting) by (29.4\%), indicating that the sample members are qualified to understand the terms of the instrument of the study. The age group (10 - less than 15 years) was $(48.5 \%)$ which is the largest group, it indicates that the members of the sample have the necessary knowledge to perform the duties and tasks entrusted to them.

\subsection{Survey Data}

The means, standard deviations, rank and relative importance were used to describe the respondents' answers to the question paragraphs and their attitudes. The results were as follows:

\section{First: Effectiveness of Accounting Information System}

This variable was measured by relevance, reliability, and information security. Descriptive statistical measures are shown in the following table:

Table 4. Means, standard deviations, rank and relative importance of the effectiveness of accounting information systems

\begin{tabular}{|c|c|c|c|c|c|}
\hline Dimension & & Mean & Standard Deviations & Rank & Relative Importance \\
\hline Relevance & & 4.156 & 0.543 & 1 & High \\
\hline Reliability & & 4.122 & 0.527 & 2 & High \\
\hline Information Security & & 3.757 & 0.627 & 3 & High \\
\hline $\begin{array}{l}\text { Effectiveness of } \\
\text { Information System }\end{array}$ & Accounting & 4.012 & 0.497 & & High \\
\hline
\end{tabular}

Table 4 shows that the trends of the respondents were about the high relative importance of the effectiveness of the accounting information systems, where the mean was (4.012) and the standard deviation was (0.497). The dimension (Relevance) was first, with average (4.156), and standard deviation (0.543), with a high relative importance, while the dimension (Information Security) was last, with average (3.757) and standard deviation (0.627) with a high relative importance. All the dimensions of the effectiveness of accounting information systems have shown a high relative importance.

\section{Second: Electronic Audit Risk}

This variable was measured by Inherent Risk, Control Risk, and Detection Risk. Descriptive statistical measures are shown in the following table: 
Table 5. Means, standard deviations, rank and relative importance of the effectiveness of Electronic audit risk

\begin{tabular}{lllll}
\hline Dimension & Mean & Standard Deviations & Rank & Relative Importance \\
\hline Inherent Risk & 3.876 & 0.543 & 1 & High \\
Control Risk & 3.801 & 0.767 & 3 & High \\
Detection Risk & 3.825 & 0.806 & 2 & High \\
Electronic audit risk & $\mathbf{3 . 8 3 4}$ & $\mathbf{0 . 6 1 2}$ & & High \\
\hline
\end{tabular}

Table 5 shows that the trends of the respondents were about the high relative importance of the Electronic audit risk with the mean of (3.834) and the standard deviation of (0.612). The dimension (Inherent Risk) was first, with average of (3.876), and standard deviation of (0.543), with high relative importance, while the dimension (Control Risk) was last, with average of (3.801) and standard deviation of $(0.767)$, with a high relative importance. All the dimensions of the Electronic audit risk have shown a high relative importance.

\section{Hypotheses Testing}

The study relied on multiple regression analysis to test hypotheses. It was necessary to ensure that the data were free from the multicollinearity phenomenon. This phenomenon indicates that there is perfect linear relationship between two or more variables. To test the existence of multicollinearity phenomena between model variables, Pearson correlation coefficients was calculated between independent (predictor) variables. The results of testing multicollinearty between independents variables are explained by correlation matrix as following:

Table 6. The correlation matrix for the independent variables

\begin{tabular}{llll}
\hline Variable & Relevance & Reliability & Information Security \\
\hline Relevance & 1 & & \\
Reliability & $0.750^{* *}$ & 1 & $\mathbf{1}$ \\
Information Security & $0.563^{* *}$ & $0.669^{* *}$ & \\
\hline
\end{tabular}

** significant at 0.01 .

Table 6 shows that the highest value of the correlation coefficient was recorded between the independent variables (relevance) and (reliability), which reached $(0.750)$, while the values of correlation coefficient between the other independent variables were lower, indicating that there is no linear correlation phenomenon (Gajarati 2004: 359). Therefore, it can be said that the sample of the study is free from the problem of multiple linear high correlation.

\subsection{The Results of the Main Hypothesis Test}

H0: There is no statistically significant effect on the effectiveness of accounting information systems (relevance, reliability, information security) on the Electronic audit risk (inherent, control, detection) in Irbid Electricity Company.

To test this hypothesis, multiple linear regression analysis was used, and the results were as shown in Table (7) as follows:

Table 7. The results of the main hypothesis test $\mathrm{H} 0$

\begin{tabular}{llllll}
\hline \multirow{2}{*}{ Dependent Variable } & Independent Variables & \multicolumn{2}{l}{ Coefficients } & \\
& & $\mathrm{B}$ & Std. Error & T Calculated & $\begin{array}{l}\text { Sig. } t^{*} \\
\text { Significance Level }\end{array}$ \\
\hline \multirow{3}{*}{ Electronic audit risk } & Relevance & 0.105 & 0.092 & 1.142 & 0.255 \\
& Reliability & 0.563 & 0.105 & 5.348 & 0.000 \\
& Information Security & 0.289 & 0.071 & 4.069 & 0.000 \\
Correlation Coefficient R & 0.788 & & & \\
Coefficient of determination $\mathrm{R}^{2}$ & 0.621 & & & \\
F value & 72.223 & & & \\
Sig. $\mathrm{F}^{*}$ & 0.000 & & &
\end{tabular}

* Significant at $(\alpha \leq 0.05)$. 
The results of table 7 indicate that the correlation coefficient $(\mathrm{R}=0.788)$ refers to the relationship between independent and dependent variables. The effect of the independent variables (the effectiveness of the accounting information systems) on the dependent variable (e-audit risk) is statistically significant, where the calculated $\mathrm{F}$ value is (72.223), with significant level $(\mathrm{Sig}=0.000)$ is less than 0.05 . The value of the coefficient of determination $\left(\mathrm{R}^{2}=0.621\right)$ was shown to indicate that $(62.1 \%)$ of the variance in the (electronic audit risk) could be explained by the variance in the (effectiveness of accounting information systems).

The table of coefficients showed that the value of $\mathrm{B}$ at (relevance) was $(0.105)$ with $t$ value (1.142) and significance level $(\mathrm{Sig}=0.255)$, indicating that the effect of this dimension is insignificant. The value of $\mathrm{B}$ at (reliability) was ( 0.563$)$ with $\mathrm{t}$ value (5.348) and significance level $(\mathrm{Sig}=0.000)$, indicating that the effect of this dimension is significant. Also, the value of B at (information security) was (0.289), with $t$ value (4.069), and significance level $(\mathrm{Sig}=0.000)$, indicating that the effect of this dimension is significant.

Based on the above discussion, the null hypothesis was rejected and alternative one was accepted, this led to the following results:

There is a statistically significant effect on the effectiveness of accounting information systems (relevance, reliability, information security) on the Electronic audit risk (inherent, control, detection) in Irbid Electricity Company.

\subsection{The results of the Sub-Hypotheses Test}

The sub-hypotheses of the study were tested to calculate the interpretation ratio and to determine the most important dimensions of the electronic auditing risks: inherent risks, control risks, and Detection Risks that are affected by the effectiveness of the combined accounting information systems, the results were as follows:

Table 8. The results of the Sub-hypotheses test

\begin{tabular}{|c|c|c|c|c|}
\hline $\begin{array}{l}\text { Independent Variables } \\
\text { effectiveness of the } \\
\text { systems }\end{array}$ & accounting information & $\begin{array}{l}\text { Dependent Variable } \\
\text { inherent risks } \\
\text { H01 }\end{array}$ & $\begin{array}{l}\text { control risks } \\
\mathrm{H} 02\end{array}$ & $\begin{array}{l}\text { Detection Risks } \\
\text { H03 }\end{array}$ \\
\hline \multirow[t]{4}{*}{ Relevance } & $\begin{array}{l}\text { Regression coefficient } \\
\text { B }\end{array}$ & 0.389 & 0.103 & 0.029 \\
\hline & Std. Error & 0.098 & 0.123 & 0.148 \\
\hline & T Calculated & 3.982 & 0.839 & 0.193 \\
\hline & Sig t* & 0.000 & 0.403 & 0.847 \\
\hline \multirow[t]{4}{*}{ Reliability } & $\begin{array}{l}\text { Regression coefficient } \\
\text { B }\end{array}$ & 0.219 & 0.708 & 0.760 \\
\hline & Std. Error & 0.112 & 0.141 & 0.170 \\
\hline & T Calculated & 1.959 & 5.036 & 4.485 \\
\hline & Sig t* & 0.052 & 0.000 & 0.000 \\
\hline \multirow[t]{4}{*}{$\begin{array}{l}\text { Information } \\
\text { Security }\end{array}$} & $\begin{array}{l}\text { Regression coefficient } \\
\text { B }\end{array}$ & 0.132 & 0.482 & 0.252 \\
\hline & Std. Error & 0.075 & 0.095 & 0.114 \\
\hline & T Calculated & 1.746 & 5.087 & 2.201 \\
\hline & Sig $t^{*}$ & 0.083 & 0.000 & 0.029 \\
\hline \multicolumn{2}{|c|}{ Correlation Coefficient R } & 0.675 & 0.754 & 0.659 \\
\hline \multicolumn{2}{|c|}{ Coefficient of determination $\mathrm{R}^{2}$} & 0.455 & 0.569 & 0.434 \\
\hline \multicolumn{2}{|l|}{ F value } & 36.748 & 58.094 & 33.759 \\
\hline \multicolumn{2}{|l|}{ Sig. F* } & 0.000 & 0.000 & 0.000 \\
\hline
\end{tabular}

*significant at $(\alpha \leq 0.05)$.

Table 8 presents the results of hypotheses test that are branching from the main hypothesis of the study as follows:

\section{1- The results of first sub-hypothesis test H01:}

The results of table (8) indicate that the correlation coefficient $(\mathrm{R}=0.675)$ refers to the relationship between independent and dependent variables. The effect of the independent variables (the effectiveness of the accounting information systems) on the dependent variable (inherent risk) is statistically significant, where the calculated $\mathrm{F}$ value is (36.748), and the significant level ( $\mathrm{Sig}=0.000)$ is less than 0.05 . The value of the coefficient of determination $\left(\mathrm{R}^{2}=0.455\right)$ was shown to indicate that $(45.5 \%)$ of the variance in the (inherent risk) could be explained by the variance in the (effectiveness of accounting information systems) combined. The table of coefficients showed that there was an effect in the dimension (Relevance), while the effect did not appear at all 
in (reliability, information security).Therefore, the researcher rejects the first null sub-hypothesis and accepts the alternative hypothesis which illustrates that:

There is a statistically significant effect on the effectiveness of accounting information systems (relevance, reliability, information security) on the inherent risks in Irbid Electricity Company.

\section{2- The results of second sub-hypothesis test $\mathrm{HO2}$ :}

The results of Table (8) indicate that the correlation coefficient $(\mathrm{R}=0.754)$ refers to the relationship between independent and dependent variables. The effect of the independent variables (the effectiveness of the accounting information systems) on the dependent variable (control risks) is statistically significant, where the calculated $\mathrm{F}$ value is (58.094), and the significant level $(\mathrm{Sig}=0.000)$ is less than 0.05 . The value of the coefficient of determination $\left(\mathrm{R}^{2}=0.569\right)$ was shown to indicate that $(56.9 \%)$ of the variance in the (control risks) could be explained by the variance in the (effectiveness of accounting information systems) combined. The table of coefficients showed that there was an effect in both the dimensions (reliability, and information security), while the effect did not appear at (relevance).Therefore, we reject the second null sub-hypothesis and accept the alternative hypothesis which illustrates that:

There is a statistically significant effect on the effectiveness of accounting information systems (relevance, reliability, information security) on the control risks in Irbid Electricity Company.

\section{3- The results of third sub-hypothesis test $\mathrm{HO3}$ :}

The results of Table (8) indicate that the correlation coefficient $(\mathrm{R}=0.659)$ refers to the relationship between independent and dependent variables. The effect of the independent variables (the effectiveness of the accounting information systems) on the dependent variable (Detection Risks) is statistically significant, where the calculated $\mathrm{F}$ value is $(33.759)$, and the significant level $(\mathrm{Sig}=0.000)$ is less than 0.05 . The value of the coefficient of determination $\left(\mathrm{R}^{2}=0.434\right)$ was shown to indicate that $(43.4 \%)$ of the variance in the (Detection Risks) could be explained by the variance in the (effectiveness of accounting information systems) combined. The table of coefficients showed that there was an effect in both dimensions (reliability, and information security), while the effect did not appear at (relevance).Therefore, the researcher rejects the third null sub-hypothesis and accepts the alternative hypothesis which illustrates that:

There is a statistically significant effect on the effectiveness of accounting information systems (relevance, reliability, information security) on the Detection Risks in Irbid Electricity Company.

\section{Conclusions and Recommendations}

\subsection{Conclusions}

According to the results of descriptive analysis and hypothesis testing, the following conclusions were obtained:

1- The results of the descriptive analysis showed that the trends of the respondents were about approving the efficiency of the accounting information systems at Irbid Electricity Company, with a high relative importance. The dimension (Relevance) came first, followed by (reliability), and then (information security) in third ranked and last with a high relative importance to all dimensions.

2- The results of the descriptive analysis showed that the trends of the respondents were to agree that the Irbid Electricity Company seeks to reduce the risks of electronic auditing and the relative importance of high. The dimension (inherent risk) came first, followed by (Detection Risks), and then (control risks) in third ranked and last with a high relative importance to all dimensions.

3- The results of the main study hypothesis showed that there is a significant effect on the effectiveness of accounting information systems (relevance, reliability, information security) on the Electronic audit risk (inherent risks, control risks, and Detection Risks) at Irbid Electricity Company. The impact was found at reliability, and information security, while the effect did not appear at relevance.

4- The results of the hypothesis test, which is part of the main hypothesis of the study, revealed a significant effect of the efficiency of the accounting information systems (relevance, reliability, information security) on the Electronic audit risk (inherent risks, control risks, and Detection Risks) at Irbid Electricity Company, when examining the impact of each type of risk individually.

\subsection{Recommendations}

Based on the findings, the researcher recommends the followings: 
1. There is a need to work towards achieving compatibility and harmony between the accounting information systems and the applied administrative information systems in order to integrate information in Irbid Electricity Company.

2. Increasing the degree of reliability of the information provided by the accounting information systems applied in the company through achieving efficiency and effectiveness in it.

3. Adopting methods and procedures which aim at ensuring the retrieval of data and information when lost due to malfunctioning devices or natural disasters, and adopting appropriate technical methods and techniques to limit the unauthorized use of computerized processing system.

4. Take many effective measures to reduce inherent risks, and taking into account the size of the company when assessing inherent risks.

5. Stimulate employees to participate in programs and training courses that increase mental and intellectual brainstorming, a matter which helps in lowering the level of control risks.

6. Work to achieve effectiveness and efficiency in accounting control procedures and set protection programs to reduce expected control risks.

7. Following audit procedures characterized by effectiveness, efficiency and accuracy, because of their role in reducing the risk of discovery.

\section{References}

Abu Zer, O. (2016). The Impact of Accounting Information Systems on the Market Value of Jordanian Companies. Unpublished $\mathrm{PhD}$ dissertation. University of Islamic International Sciences. Amman: Jordan.

Abu, O., \& Areej, A. (2016). The Effect of Electronic Risks on the Efficiency of Auditing from the Viewpoint of the Jordanian External Auditors. Unpublished M.A. Thesis. Al Albait University, Mafraq-Jordan.

Al-Husseini, Q. I. (2009). Accounting Information Systems. Dar Al-Marikh. Amman, Jordan.

Alokour, S. (2014). Effect of the Effectiveness of Accounting Information Systems on the Operational and Financial Performance of Industrial Corporations in Jordan. Published $\mathrm{PhD}$ dissertation, University of Islamic International Sciences, Amman-Jordan.

Alshahneh, R. A. Z. (2015). Accountants' Auditing Modern Entrance According to the International Auditing Scales: Theoretical Framework (1st ed.). Wael Publishing House. Amman-Jordan.

Aziz, F. (2014). The Role of Electronic Auditing in Reducing the Risk of Banking Auditing. paper submitted to the CPA Association of CPAs, Baghdad: Iraq.

Barzan, S. (2015). The Effect of Electronic Auditing on Raising Independence and Efficiency of the Internal Auditor. Journal of Economic and Administrative Sciences, 21(84), 415-441.

Dbaghiyeh, M., \& Alsadi, I. K. (2011). The Effect of the Environmental Components on the Efficiency and Interactivity of Accounting Information Systems in the Assurance Companies: Analytical Study of the Jordanian Assurance Companies. Management and economy Journal, 34(90).

Demartini, C., \& Trucco, S. (2016). Does Intellectual Capital Disclosure Matter for Audit Risk? Evidence from the UK and Italy. https://doi.org/10.3390/su8090867

Gonzalez, G., \& Hoffman, V. (2018). Effects on Auditees of Electronic versus Face-to-Face Interaction in Continuous Auditing. Journal of Forensic \& Investigative Accounting, 1(10), 100-115.

Hall, J. (2016). Accounting information systems (8th ed.). Pearson Education: USA.

International Federation of Accountants. (2010). Issued International Standards for Quality Control, Auditing, Reference and Other Confirmations and Related Services. Translation of the Arab Society of Certified Accountants, Amman-Jordan.

Jawabreh, O., \& Alrabei, A. (2013). The Impact of Accounting Information System in Planning, Controlling and Decision-Making Processes in Jodhpur Hotels. Asian Journal of Finance and Accounting, 4(1), 173-188.

Keiso, W., \& Warfield. (2016). Intermediate Accounting. John Wiley \& Sons, Inc.: USA .

Kharabsheh, O. (2018). The Impact of Accounting Information Systems on Cost Reduction under Cloud Computing. Unpublished M.A. Thesis, Jerash University: Amman-Jordan.

Luo, L. (2011). Are Audit Programs Responsive to Audit Risk? Doctor Thesis, University of Alberta: Canada. 
Mushtahi, S. M., Hamdan, A. M., \& Shaker, T. H. (2011). The reliability of accounting information systems and their impact on improving the performance indicators of banking, a comparative study on Jordanian and Palestinian banks listed on the Amman and Nablus Stock Exchanges. Journal of Administrative Sciences Studies, 38(1), 21-46.

Nathmi, E. A., \& Tarek, H. (2015). To Measure the Extent of Internal Audit Based on Business Risk in the Banks of the United Arab Emirates and the Factors Influencing it. Koot Journal of Economic and Administrative Sciences Applied, (18), 130-137.

Pavel, N. (2015). Study Regarding Information Audit for E-business. Audit Financier, 90-99.

Rommeny, M., \& Stenbart, P. (2016). Accounting Information Systems (14th ed.). Pearson Education: USA.

Shaat, M. (2013). The impact E-commerce on the external auditor work. Unpublished M.A. Thesis. Islamic university of Gaza. Gaza-Plestine.

Sofian, B. (2012). Accounting Information System and its Role in the Management of the Economic Institution. Unpublished M.A. Thesis, Montauri University, Constantinople, Algeria.

\section{Copyrights}

Copyright for this article is retained by the author(s), with first publication rights granted to the journal.

This is an open-access article distributed under the terms and conditions of the Creative Commons Attribution license (http://creativecommons.org/licenses/by/4.0/). 